\title{
Een evidence-based interventieprogramma gericht op preventie en reïntegratie van NEETs in Limburg
}

Citation for published version (APA):

Levels, M. (2020). Een evidence-based interventieprogramma gericht op preventie en reïntegratie van NEETs in Limburg. ROA. ROA Technical Reports No. 007 https://doi.org/10.26481/umarot.2020007

Document status and date:

Published: 31/08/2020

DOI:

10.26481/umarot.2020007

Document Version:

Publisher's PDF, also known as Version of record

\section{Please check the document version of this publication:}

- A submitted manuscript is the version of the article upon submission and before peer-review. There can be important differences between the submitted version and the official published version of record.

People interested in the research are advised to contact the author for the final version of the publication, or visit the DOI to the publisher's website.

- The final author version and the galley proof are versions of the publication after peer review.

- The final published version features the final layout of the paper including the volume, issue and page numbers.

Link to publication

\footnotetext{
General rights rights.

- You may freely distribute the URL identifying the publication in the public portal. please follow below link for the End User Agreement:

www.umlib.nl/taverne-license

Take down policy

If you believe that this document breaches copyright please contact us at:

repository@maastrichtuniversity.nl

providing details and we will investigate your claim.
}

Copyright and moral rights for the publications made accessible in the public portal are retained by the authors and/or other copyright owners and it is a condition of accessing publications that users recognise and abide by the legal requirements associated with these

- Users may download and print one copy of any publication from the public portal for the purpose of private study or research.

- You may not further distribute the material or use it for any profit-making activity or commercial gain

If the publication is distributed under the terms of Article $25 \mathrm{fa}$ of the Dutch Copyright Act, indicated by the "Taverne" license above, 


\section{Maastricht University ROA}

\section{Een evidence-based interventieprogramma gericht op preventie en reïntegratie van NEETs in Limburg}

Mark Levels

\section{ROA Technical Report}

ROA-TR-2020/7

Researchcentrum voor Onderwijs en Arbeidsmarkt | ROA Research Centre for Education and the Labour Market / ROA 


\title{
Een evidence-based interventieprogramma gericht op preventie en reïntegratie van NEETs in Limburg
}

\author{
Mark Levels
}

ROA-TR-2020/7

July 2020

Research Centre for Education and the Labour Market Maastricht University

P.O. Box 616, 6200 MD Maastricht, The Netherlands

$\mathrm{T}+31433883647 \mathrm{~F}+31433884914$

secretary-roa-sbe@maastrichtuniversity.nl

www.roa.nl

ISSN: $2666-884 X$ 


\section{Waarom NEET?}

NEETs zijn jonge mensen die niet werken, niet op school zitten, en geen trainingen of cursussen volgen (ze zijn dus Not in Employment, Education, or Training). Net als elders in de wereld vormen NEETs ook in Limburg een grote sociale en economische uitdaging. Jongeren die vroeg buiten de arbeidsmarkt terechtkomen staan hun hele verdere leven op een onoverbrugbare achterstand: ze reïntegreren moeilijk, sukkelen van de ene marginale baan naar de andere en zijn vaker sociaal geïsoleerd. Er zijn ook grote maatschappelijke kosten. NEETs zijn veel vaker ongewenst ouder en veel vaker crimineel. Maar NEETs zijn ook een groot economisch probleem. Deze jongeren kosten de samenleving veel geld: in directe uitkeringen, gemiste productiviteit en gemiste belastingen, maar ook in kosten rondom maatschappelijke hulpverlening en handhaving. Europese landen samen zijn aan NEETs jaarlijks niet minder dan 156 miljard euro kwijt. NEET laten integreren betekent dat deze sociale, maatschappelijke en economische kosten in belangrijke mate omlaag kunnen.

Nederland behoort tot de landen in de wereld met het laagste aantal NEETs. Limburg is de uitzondering op die regel. Bovendien stijgt het aantal NEETs tegen de landelijke trend in nog steeds in Limburg. Eerder onderzoek dat het ROA in het kader van 4Limburg deed, laat zien dat de NEETs met de grootste afstand tot de arbeidsmarkt zich in overweldigende meerderheid bevinden in de Oostelijke Mijnstreek.

In het 4Limburg-programma hebben we beloofd experimentele interventies te ontwikkelen die erin zouden kunnen slagen om te voorkomen dat jonge mensen NEET worden, of NEETs weer aan het werk zouden kunnen krijgen. Het betrouwbare internationale wetenschappelijke bewijs is evenwel schaars, en bovendien over het algemeen methodologisch beperkt. In beginsel moet een goed evaluatie zo worden uitgevoerd dat we op basis van bevindingen in staat worden gesteld harde uitspraken te doen over de effectiviteit van de interventies. Daarvoor is experimenteel onderzoek het meest geschikt. Dergelijk onderzoek bestaat nog nauwelijks, en de bruikbaarheid van het bestaande evaluatiestudies voor de specifieke Limburgse situatie is zeer beperkt. Er is daardoor geen duidelijkheid over de wijze waarop we NEETs in Limburg weer aan de slag krijgen.

Daar kunnen we iets aan doen. In dit rapport presenteren we twee concrete voorstellen voor experimenten die ten doel hebben het aantal NEETs in Limburg te verminderen. Onderzoekers van de Universiteit Maastricht hebben daartoe samen met vertegenwoordigers van verschillende Limburgse maatschappelijke organisaties en provinciale kennisinstellingen (waaronder Hogeschool Zuyd en 
Jeugd GGZ Maastricht) twee interventies ontworpen die eigenschappen van verschillende succesvolle interventies combineren. We stellen voor de interventies in een evidence based beleidscyclus in te voeren. De cyclus helpt om interventies te implementeren en op basis van gedegen wetenschappelijk bewijs bij te sturen, om zo de effectiviteit te vergroten. Daarmee wordt tevens voorkomen dat er onverantwoorde publieke kosten worden gemaakt.

Aan de totstandkoming van het ontwerp van deze experimenten werkten naast de vele vertegenwoordiges van maatschappelijke organisaties, de volgende onderzoekers mee:

- prof. dr. Philip Delespaul (FHML): mHealth interventie, PsyMate, en het veldexperiment "Preventie van NEET door terugdringen VSV in het Mbo"

- prof. dr. Therese van Amelsfoort (FPN): mHealth interventie, PsyMate, en het veldexperiment "Preventie van NEET door terugdringen VSV in het Mbo"

- Irmgard Tummers, MA, BTC (Hogeschool Zuyd): kwalitatieve studies

- prof. dr. Andries de Grip (ROA/ 4Limburg): beide interventies

- prof. dr. Mark Levels (ROA/ 4Limburg): beide interventies

- drs. Alexander Dicks (ROA): het veldexperiment "Reïntegratie van NEETs - Neet in Parkstad" 


\title{
2. Experiment 1: Reïntegratie van NEETs - "Neet in Parkstad"
}

\author{
Alexander Dicks \& Mark Levels
}

Uit de twee 4Limburg factsheets (Levels, de Grip en Dicks, 2018; Levels, Dicks en de Grip, 2020) is gebleken dat slechts een deel van de Limburgse NEETs langdurig kwetsbaar is. Experiment 1 richt zich op deze meest kwetsbare groep. Het experiment is een voorstel voor een meerjarig evidence based interventieprogramma dat als doel heeft het aantal Limburgse jongeren dat langdurig buiten de arbeidsmarkt of het onderwijs terecht is gekomen drastisch te reduceren. Dit programma is tot stand gekomen door samenwerking van groot aantal maatschappelijke organisaties en Limburgse kennisinstellingen. We focussen op de Oostelijke Mijnstreek, omdat daar de problematiek van de langdurige NEETs het meest dringend lijkt te zijn.

\subsection{Interventie "Neet in Parkstad"}

Het aantal programma's dat in Nederland is uitgerold in het kader van de Aanpak Jeugdwerkloosheid is zeer divers, maar wat een groot deel van de kennelijk werkzame interventies in algemene zin met elkaar gemeen lijken te hebben is:

a) een zeer persoonlijke aanpak van een hulpverlener, die zich om de jongere bekommert, niet oordeelt maar luistert, achterhaalt wat de bariere is, en die bariere helpt weg te nemen (zie bijvoorbeeld Soons, Heerlen);

b) een heldere, haalbare, voorop vastgestelde doelstelling. Dat is hier: het vinden van een passende arbeidsplaats of vervolgopleiding, en die arbeidsplaats of vervolgopleiding zeker een halfjaar vasthouden;

c) een lage overheidsbetrokkenheid. De hulpverlener komt niet (of althans niet zichtbaar) vanuit de overheid. De overheid wordt door veel jongeren gezien als een natuurlijke vijand;

d) een goede samenwerking met stakeholders die jongeren eventueel willen of kunnen plaatsen. Dat zijn in dit geval scholen en werkgevers.

Deze factoren lijken afzonderlijk sterk bij te dragen aan het succes van andere op jeugd gerichte interventies in Limburg en in de rest van het land, en zijn allemaal sterk ingebed in zowel de praktische als wetenschappelijke literatuur over succesvolle reïntegratietrajecten. Door deze factoren met elkaar te combineren tot een enkele, uniforme interventie, beoogt de voorgestelde methodiek het aantal 
hardnekkige, langdurige NEETs in de Oostelijke Mijnstreek substantieel te verlagen. Concreet kent de interventie de volgende eigenschappen:

- We willen in Limburg actieve maatschappelijke organisaties uit ons netwerk uitnodigen zich specifiek op NEETs in de Oostelijke Mijnstreek te concentreren, en in hun aanpak de "Neet in Parkstad"-methode toe te passen.

- Deelname is op basis van vrijwilligheid. Jongeren melden zich zelf aan voor de interventie.

- De jongeren die gekozen worden voor het "NEET in Parkstad" programma gaan een traject in van ten hoogste 8 weken, waarbij een hulpverlener (die zichzelf uitdrukkelijk niet als overheidsambtenaar afficieert) door middel van persoonlijke gesprekken probeert te achterhalen wat de NEET motiveert en welke levensdoelen hij of zij heeft. Ook wordt achterhaald welke praktische drempels de NEET ondervindt bij het bereiken van deze levensdoelen. In een intensief begeleidingstraject worden deze drempels door jongere en hulpverlener geaddresseerd, en verlaagd of weggenomen.

- Het programma is gericht op een succesvolle reïntegratie, hetzij naar de arbeidsmarkt, dan wel naar het onderwijs.

- Een geslaagde interventie betekent dat een jongere die voorheen NEET was, een baan vindt of een opleiding gaat volgen, en dat minimaal een halfjaar blijft doen. De hulpverlener maakt daartoe gebruik van een netwerk van welwillende werkgevers en onderwijsinstellingen.

\subsection{Uitrollen en op basis van wetenschappelijk bewijs de effectiviteit verbeteren}

Gegeven het succes van dergelijke programma's, zowel in Nederland als daarbuiten, is het afbreukrisico in Limburg erg klein. Maar dat iets op de ene plaats werkt, wil niet zeggen dat het ook op de andere plaats werkt. Bovendien willen we ernaar streven om de effectiviteit van de interventies te optimaliseren: dat iets werkt, wil niet zeggen dat met deze aanpak het maximale effect bereikt is. We stellen daarom voor een slimme cyclus van evidence base beleidsinterventies te organiseren, waarmee we kunnen garanderen dat we de effectiviteit van onze interventie maximeren.

We stellen daartoe voor dat de wetenschappers en onderzoekers van de Universiteit Maastricht en Hogeschool Zuyd het implementatietraject met een gedegen evaluatiestudie begeleiden. De onderzoekers kunnen door middel van een veldexperiment en aanvullend kwalitatief onderzoek hard vaststellen wat de causale impact van onze interventie is op de reïntegratie van jongeren. Het kwantitatieve onderzoek beoogt vast te stellen welke interventie werkt en op welke plaatsen en onder welke omstandigheden de interventie het beste werkt; het kwalitatieve onderzoek brengt aan het licht waarom. 
Om dit te organiseren, moet de voorgestelde interventie worden uitgevoerd als veldexperiment. Daarmee wordt geprobeerd de expermentele condities van een wetenschappelijk experiment zo goed mogelijk na te bootsen in de praktijk. Dat komt er op neer dat deelnemers in twee groepen moeten worden ingedeeld. Van alle deelnemers volgt 50\% een regulier programma ("controlegroep") en $50 \%$ het "NEET in Parkstad" programma ("interventiegroep"). Toewijzing is willekeurig, zodat eventuele verschillen in uitkomsten uitsluitend kunnen worden toegeschreven aan de interventie. Van alle jongeren wordt dan na 8 weken vastgelegd of ze een baan hebben gevonden of een opleiding zijn gaan volgen. Van de jongeren voor wie dit geldt, kan dan na 6 maanden worden vastgelegd of ze deze baan nog steeds hebben.

\subsection{Implementatie van het eerste experiment}

Concreet behelst de implementatie van interventie een tiental opeenvolgende fases, die beogen de doelmatigheid van de interventie te maximaliseren en tevens de effectiviteit te meten. Deze fases zijn:

1. Vinden van NEETs

2. Aanmeldingen administreren

3. Kwalitatief onderzoek

4. Voormeting (survey naar een aantal kenmerken)

5. Toewijzen van NEET aan caseworkers

6. Treatment

7. Nameting

8. Registeronderzoek

9. Effectevaluatie

10. Beleidswijziging

We zetten deze fases hieronder kort uiteen. Vooraf dient de projectleiding en -inrichting van het projectteam geborgd te zijn, en dienen gekwalificeerde caseworkers te worden geselecteerd en getraind (zie ook: noodzakelijke voorwaarden).

\section{Vinden van NEETs}

Een van de belangrijkste uitdagingen bij het onderzoek naar NEETs is het vinden van deze jongeren. NEETs zijn bijna per definitie sociaal geïsoleerd en daardoor moeilijk te bereiken via gebruikelijke kanalen (werk of school). Niet zelden verdwijnen ze helemaal van de radar, ook bij maatschappelijke organisaties. Ook zijn ze vaak teruggetrokken, waardoor ze nog moeilijker te bereiken zijn. Deze 
interventie mikt bovendien vooral op de moeilijkst te bereiken groep. We stellen daarom een driesporenbeleid voor, waarin we de jongeren om wie het gaat, opsporen:

- Via het bestaande netwerk van gemeenten en maatschappelijke organisaties. Zo hebben de VKK goed zicht op problematische jongeren in kleinere kernen; caseworkers bij de gemeenten Heerlen, Kerkrade en Landgraaf weten welke jongeren in hun kaartenbakken het meest hardnekkig zijn. De Dienst Kerk en Samenleving staat midden in de wijken, en heeft inloophuizen waar jongeren op de hoogte gesteld kunnen worden van het programma.

- Via sociale media. Veel van de jongeren zijn wel actief op internet, en dus via sociale media te bereiken. De Hogeschool Zuyd (lectoraat HRM) is een vooronderzoek gestart naar de mogelijkheden deze jongeren via sociale media te bereiken, dat we veelbelovend vinden.

- Via concrete wervingsacties in de woonomgevingen van NEETs. Een van Limburgs meest succesvolle reintegratieacties is gedaan door Lieve Schouterden, die een grote groep langdurig werklozen heeft geholpen weer te reintegreren. Zij wierf langdurig werklozen succesvol aan door in hun woonomgeving te adverteren. Een dergelijke opzet zou ook hier gevolgd kunnen worden. Leefbaarheidsmedewerkers van woningstichtingen als Wonen Limburg en Wonen Zuyd hebben goed in kaart waar de meest problematische jongeren wonen. Deze gegevens mogen ze om AVG-redenen niet delen met derden; wel mogen ze hulpverleners de buurten aanwijzen waar jongeren wonen. In deze buurten kunnen jongeren door middel van directe wervingsacties (flyers, folders, abri's) bereikt worden.

De wervingsperiode van de NEETs zou niet langer dan drie maanden moeten duren.

\section{Aanmeldingen administreren}

Jongeren moeten zich gedurende de hele wervingsperiode voor het programma kunnen aanmelden. De administratie van de aanmeldingen vindt centraal plaats, bij voorkeur bij een maatschappelijke organisatie zodat de drempel laag is. Daarvoor moet een toegankelijk en voor jongeren goed bereikbaar kanaal worden ingericht, dat bij voorkeur via social media of WhatsApp bereikbaar is. Hulpverleners van gemeenten of MO's kunnen jongeren eventueel helpen zich aan te melden. $\mathrm{Na}$ aanmelding gaat de interventie direct van start.

\section{Kwalitatief onderzoek}

Om de interventies in Limburg op lange termijn zo effectief mogelijk te maken, is het nodig te achterhalen waarom het programma voor sommige jongeren beter werkt dan voor anderen. Hiertoe 
is kwalitatief onderzoek noodzakelijk. Om een goed beeld te krijgen van mogelijke verklaringen voor de effectiviteit zullen tenminste 30 diepteinterviews moeten plaatsvinden.

\section{Voormeting (survey naar een aantal kenmerken)}

Er dient een voormeting plaats te vinden. De sociaal-economische status van de jongeren wordt formeel vastgesteld, alsmede hun afstand tot onderwijs en arbeidsmarkt. Daarnaast moet een bescheiden vragenlijstje afgenomen worden bij alle jongeren die zich aanmelden. In dat vragenlijstje wordt een aantal achtergrondkenmerken uitgevraagd, en wordt een eerste inventarisatie van mogelijke uitdagingen gemaakt. Deze vragenlijst is ook belangrijk voor het welslagen van de veldexperimentele toets op de effectiviteit, omdat de informatie helpt om vast te stellen of de interventiegroep en de controlegroep op belangrijke kenmerken op elkaar lijken.

\section{Toewijzen van NEET aan caseworkers}

In de volgende fase moeten NEETs aan caseworkers worden gekoppeld. Dat koppelen dient gerandomiseerd te gebeuren, waarbij 50\% van alle jongeren aan de treatmentgroep moeten worden toegewezen, en $50 \%$ aan de controlegroep. Alleen de caseworkers in de treatmentgroep volgen de NEET-in-Parkstadmethodiek.

\section{Treatment}

Dit is een periode die in totaal 24 weken omvat. Tijdens deze periode vinden de 100 interventies plaats zoals hierboven omschreven. De jongeren gaan een traject in van ten hoogste 8 weken, waarbij de volgende stappen worden doorlopenL

- Een hulpverlener zichzelf uitdrukkelijk niet als overheidsambtenaar afficieert) achterhaalt door middel van minstens twee persoonlijke gesprekken wat de NEET motiveert en welke levensdoelen hij of zij heeft.

- Middels een gestructureerd interview worden praktische drempels die de NEET ondervindt bij het bereiken van deze levensdoelen in kaart gebracht.

- De caseworker stelt in dialoog met de NEET een persoonlijk en op maat gemaakt begeleidingstraject op, dat acht weken duurt. Dat traject wordt voorgelegd aan tenminste een andere hulpverlener, in het kader van professionele intervisie.

- In dat begeleidingstraject (dat acht weken duurt) worden deze drempels door jongere en hulpverlener samen geaddresseerd, en verlaagd of weggenomen. 


\section{Nameting}

$\mathrm{Na}$ het einde van iedere interventie moet worden nagegaan of de jongere een baan heeft gevonden of een opleiding of cursus is gestart. Na zes maanden moet worden bezien of de jongere die baan of opleiding nog niet verlaten hebben. Zes maanden na het einde van de treatmentperiode kan de totale balans worden opgemaakt.

\section{Registeronderzoek}

Daarnaast kunnen in de registers van het CBS de mensen die als NEET kunnen worden gedefinieerd en in de Oostelijke Mijnstreek woonachtig zijn, worden opgezocht. Ook van hen kan worden vastgesteld of en in hoeverre ze gedurende de looptijd van het onderzoek aan een baan of opleiding zijn begonnen en deze op langere termijn wisten te behouden. Deze groep kan een benchmark vormen, die het mogelijk maakt ook het belang van zelfselectie (de NEETs moeten zichzelf aanmelden) en vindstrategieën (de NEETs moeten bereikt worden) voor de effectiviteit van de interventies inzichtelijk en meetbaar te maken.

\section{Effectevaluatie}

Door kwantitatief en kwalitatief onderzoek te combineren, kan worden nagegaan hoeveel jongeren in de verschillende groepen zijn gereïntegreerd, in welke mate deze integratie daadwerkelijk causaal is toe te schrijven aan de interventies, en waarom de interventie in sommige gevallen wel, en in andere gevallen niet werkt. We berekenen daarbij de kansen op betekenisvolle reïntegratie voor drie groepen:

- De algemene populatie NEETs in de Oostenlijke Mijnstreek

- De controlegroep

- De interventiegroep.

De willekeurigheid van de toewijzing aan interventie- en controlegroep maakt het mogelijk vast te stellen of de geobserveerde reïntegratie ook oorzakelijk het gevolg is van de "NEET in Parkstad"interventie. Het is mogelijk om in de statistische analyses te controleren voor heterogeniteit van interventies in de controlegroep. Het ligt daarnaast erg voor de hand dat een aantal nu al gangbare interventies een of meerdere elementen uit de "NEET in Parkstad"-methodiek in zich heeft. Het geobserveerde verschil zal dus toe te schrijven zijn aan aan de specifieke combinatie van factoren. 
Door slim te analyseren kunnen we beter begrijpen welke elementen uit de interventies precies belangrijk zijn, en voor wie.

\section{Beleidswijziging}

Het programma kan laten zien of (1) deze interventies werken, (2) waarom, en (3) onder welke omstandigheden. Na evaluatie van de effecten kan het beleid worden aangepast, met als doel de effectiviteit van de interventies te vergroten.

\section{$2.4 \quad$ Opbrengsten}

Dit experiment kan volgende concrete opbrengsten genereren:

- Maatschappelijke reïntegratie van een groot deel van de deelnemende jongeren.

- Een goed onderbouwde toets van de effectiviteit van het programma.

- Een rapportage van de bevindingen van het kwalitatieve onderzoek, met daarin de belangrijkste inzichten over de drijfveren van jonge langdurige NEETs.

- Beleidsadviezen voor gemeenten en provincies op basis van het evaluatieonderzoek, en op verzoek presentaties van de verkregen inzichten bij de deelnemende en andere Limburgse gemeenten.

- Een handleiding met praktische tips voor jeugdhulpverleners in de rest van de provincie en in den lande, gebaseerd op de inzichten die door het programma worden gegenereerd, met daarin een concreet stappenplan voor de implementatie van het programma in andere regio's.

\subsection{Voorbereiding en voorwaarden}

Om "NEET in Parkstad" te kunnen uitrollen, is een aantal voorbereidingsstappen noodzakelijk. En wel in ieder geval de volgende:

Commitment van maatschappelijke organisaties, zowel op operationeel niveau (de caseworkers) als op bestuurlijk niveau.

- Bedrijven en scholen bereid vinden concreet bij te dragen aan de reïntegratie van NEETs, hetzij door het bieden van een arbeidsplaats (werkgevers), dan wel door het bieden van een opleidingsplaats (scholen). Hier spelen de maatschappelijke organisaties een voortrekkersrol. Er is tussen 2017 en 2020 een aantal activeiten uitgevoerd om scholen en werkgevers te mobiliseren. 
- Woningstichtingen en gemeenten bereid vinden op postcode-6 niveau te identificeren in welke woongebieden probleemgevallen geconcentreerd zijn. Dat kan volledig conform de AVGwetgeving gedaan worden.

- Wervingsmateriaal produceren.

- Social-media portaal maken waar NEETs zich kunnen aanmelden. Eventueel door of in samenwerking met de studenten van Zuyd, Fontys, of Universiteit Maastricht.

- Maatschappelijke organisaties bereid vinden gekwalificeerde caseworkers te leveren die aan het programma willen deelnemen. Uitgaande van 100 NEETs (50 in de interventiegroep 50 in de controlegroep) zou het de voorkeur genieten 10 caseworkers op leiden in de methodiek, die elk 5 NEETs gaan begeleiden.

- Caseworkers opleiden in methode "Neet in Parkstad". Daartoe wordt een vijftal workshops georganiseerd, door onderzoekers van de Universiteit Maastricht en onder leiding van ervaren hulpverleners. 


\section{Experiment 2: Preventie van NEET door terugdringen VSV in het Mbo}

Therese van Amelsfoort, Philippe Delespaul \& Mark Levels

Uit de 4Limburg factsheets (Levels, de Grip en Dicks, 2018; Levels, Dicks en de Grip, 2020) is ook gebleken dat het voortijdig schoolverlaten een van de belangrijkste voorspellers is voor een leven als NEET in Limburg. Door het aantal VSV-ers terug te dringen, kunnen we voorkomen dat iemand NEET wordt. Experiment 2 stelt daarom voor het aantal Limburgse jongeren dat het onderwijs voortijdig en dus zonder kwalificerend diploma verlaat, flink te reduceren. Om dit programma te ontwikkelen hebben onderzoekers van verschillende faculteiten en onderzoeksgroepen van de Universiteit Maastricht samengewerkt. In het bijzonder, onderzoekers van de Faculty of Health, Medicine \& Life Sciences, de Faculty of Psychology \& Neuroscience, het Maastricht University Center of Neuroeconomics en het ROA/4Limburg-team van de School of Business and Economics.

Voortijdig schoolverlaten wordt meestal veroorzaakt door een complex aan factoren, waarbij naast sociale omstandigheden ook de mentale gezondheid een rol speelt. Een goede geestelijke gezondheid is van cruciaal belang voor de sociale, intellectuele en emotionele ontwikkeling van kinderen, die noodzakelijk zijn voor een succesvolle overgang naar volwassenheid (WHO, 2016). Niet minder dan $80 \%$ van de jongeren die een ziekte- of invaliditeitsuitkering krijgen, lijdt aan psychische problemen (CBS, 2015).

Door de mentale weerbaarheid van kwetsbare jongeren te verbeteren, kunnen we het aantal VSV-ers terugdringen en NEETs voorkomen. Stigmatisering, verlegenheid en schaamte zijn echter grote barrières voor het zoeken naar hulp (Leijdesdorff e.a. 2019). Bovendien maakt de rampzalige kloof op 18-jarige leeftijd de gezondheidszorg niet jeugdvriendelijk (Leijdesdorff e.a. 2019, Gerritsen e.a. 2019). Het is dus dringend noodzakelijk om jongeren eerder te bereiken in een voor hen meer geschikte omgeving. Deze interventie doet dat op scholen, door zich te richten op scholieren die regelmatig verzuimen. Schoolverzuim is een sterke risico-indicator voor geestelijke gezondheidsproblemen, maar ook een belangrijke voorspeller en oorzaak van lage onderwijsprestaties, schooluitval en een status als niet in werkgelegenheid, onderwijs en opleiding (Bagdi \& Vacca, 2005; Eurofound, 2012; Gottfried, 2011; Rodwel et al., 2018). Schoolbezoek en verbondenheid zijn beschermend tegen een reeks van gezondheidsrisico's in de adolescentie (Leijdesdorff in revisie 2020).

We richten ons op het Mbo, omdat scholieren die het Mbo zonder diploma verlaten een grote kans hebben NEET te worden. 


\subsection{Interventie "VSV in het Mbo"}

De interventie heeft betrekking op gepersonaliseerde mHealth-interventies ter bevordering van de geestelijke gezondheid en het vergroten van de mentale veerkracht. mHealth is de afkorting van mobile Health. Het programma werkt met behulp van smartphones en is daardoor bijzonder aantrekkelijk en gemakkelijk toegankelijk voor jongeren. De Ecological Momentary Assessment (EMA) technologie biedt een elegante strategie om informatie te verzamelen van jongeren, rekening houdend met de variabiliteit en veerkracht van de symptomen in relatie tot de dagelijkse omgevingscontext. EMA heeft een aantal voordelen ten opzichte van meer traditionele methoden voor de beoordeling van patiënten in klinische studies.

We stellen voor gebruik te maken van op maat gemaakte EMA-protocollen en de symptomen en dagelijkse activiteiten monitoren door bijvoorbeeld 10 metingen per dag te doen gedurende een periode van 6 dagen (Delespaul, 1995, van Os 2017, Verhagen 2017). Voor dit programma is EMA bij uitstek geschikt omdat het kan helpen om te ontwarren hoe de proefpersonen op epidemiologisch niveau van elkaar verschillen (bijv. demografische kenmerken of migratiestatus, SES van ouders) en hoe kinderen zich in de loop van de tijd ontwikkelen (door rijping of levensomstandigheden). Deze factoren kunnen ons helpen te begrijpen welke psychische problemen bijdragen aan voortijdig schoolverlaten.

De volgende belangrijke stap is het uitvoeren van een mHealth-interventie die als doel heeft de mentale weerbaarheid van jongeren te vergroten, en zich te richten op meerdere domeinen, afhankelijk van de persoonlijke behoeften van risicojongeren. Het doel is om mentale gezondheidsproblemen te voorkomen en daarmee het aantal vroegtijdige schoolverlaters en NEETs te verminderen. We stellen voor de bestaande modulaire, interactieve en gepersonaliseerde mHealthsondersteunde interventie (Psymate ${ }^{\mathrm{TM}}$ ) te implementeren die specifiek gericht is op meerdere psychosociale domeinen om de mentale weerbaarheid van de kinderen te vergroten en het schoolverzuim/ NEET te verminderen. De PsyMate ${ }^{\mathrm{TM}}$-app is - mede ondersteund door de Provincie Limburg - ontwikkeld door de afdeling Psychiatrie en Psychologie van de Universiteit Maastricht als hulpmiddel om grip te krijgen op psychologische problemen in het dagelijks leven

Concreet kent de interventie de volgende eigenschappen:

- PsyMate $^{\mathrm{TM}}$ is een app voor iPhone en Android smartphones, ontwikkeld om gedachten, gevoelens en gedrag in het dagelijks leven in kaart te brengen.

- De PsyMate ${ }^{\mathrm{TM}}$-app piept een paar keer per dag op willekeurige momenten. Als a app piept, wordt aan deelnemers gevraagd om op dat moment een aantal vragen in te vullen. Waar bevinden ze zich? Wat doen ze op dat moment? Hoe voelen ze zich daarbij? 
- $\mathrm{Na}$ het verzamelen van enkele gegevens worden de antwoorden in duidelijke grafieken en diagrammen weergegeven. Na verloop van tijd leren deelnemers activiteiten en gevoelens aan elkaar te koppelen. Zo kunnen ze bijvoorbeeld zien in welke omstandigheden men zich beter of slechter voelt.

- Het programma is gericht op een succesvolle preventie van VSV en NEET.

- Een geslaagde interventie betekent dat jongeren minder symptomen ontwikkelen, begeleiding zoeken als ze mentale gezondheidsklachten blijven houden, en minder vaak voortijdig schoolverlaten.

Wetenschappelijk onderzoek toont aan dat de mHealth interventie helpt om grip te krijgen op fysieke en psychische symptomen en weerbaarheid te vergroten. Beoordelingsinstrumenten voor depressie, bipolaire stoornis en psychose zijn grondig en wetenschappelijk getest. Aanvullende ESM-schalen voor bijvoorbeeld hypertensie en diabetes zijn in ontwikkeling.

\subsection{Uitrollen en op basis van bewezen effectiviteit verbeteren}

Er is een aantal mHealthprogramma's uitgevoerd, die laten zien dat deze aanpak kan werken. Maar ook hier geldt, dat iets dat op de ene plaats werkt, niet eveneens op een andere plaats werkt. Ook geldt hier dat we ernaar moeten streven om de effectiviteit van de interventies te optimaliserendoor de effectiviteit van de interventie veldexperimenteel te toetsen.

De stellen daarom voor experimenten te doen die het causale effect van die interventie op het mentale welzijn van kinderen en op het schoolverzuim/ NEET vast te stellen, en ons tevens beter leren begrijpen welke heterogene effecten we mogen verwachten, zowel op de korte als op de lange termijn. We testen dan de effectiviteit van mHealth-interventies voor het terugdringen van VSV in het Mbo. In twee veldexperimenten kunnen we het causale effect bestuderen van een volksgezondheidsinterventie met behulp van de mHealth-methode op (a) de veerkracht van jongeren, (b) stress, (c) saamhorigheidsgevoel, (d) voortijdig schoolverlaten, (e) onderwijsuitkomsten en (f) een overgang van school naar werk naar de NEET-status. Daarmee kunnen we garanderen dat we op de lange termijn effectief beleid gaan voeren.

\subsection{Implementatie van het tweede experiment}

Concreet behelst de implementatie van interventie acht opeenvolgende fases. Deze fases zijn:

1. Vinden van de doelpopulatie

2. Aanmeldingen administreren 

3. Kwalitatief onderzoek
4. Opzet veldexperimenten
5. Treatment
6. Registeronderzoek
7. Effectevaluatie
8. Beleidswijziging

We zetten de fases hieronder kort uiteen.

\section{Vinden van de doelpopulatie}

De interventie richt zich op studenten van het Mbo in Limburg. Om scholieren te bereiken is het goed samen te werken met een of meerdere grote besturen. Aan het Vista College (Mbo) bijvoorbeeld, studeren meer dan 16.000 leerlingen. Een minimum van 32 opleidingen in ROC's zou moeten worden uitgenodigd om deel te nemen, waaronder verschillende opleidingsniveaus. Deze scholen hebben de risicogroepen vaak goed op de radar. De doelpopulatie omvat alle scholieren, ongeacht hun risico op VSV. Scholieren die regelmatig verzuimen worden door de begeleiders op scholen echter in het bijzonder gewezen op het programma en aangespoord tot deelname.

\section{Aanmeldingen administreren}

Jongeren moeten zich gedurende de hele opstartperiode voor het programma kunnen aanmelden. De administratie van de aanmeldingen vindt centraal plaats, bij voorkeur bij de deelnemende scholen.

Insluitingscriteria:

- Deelname aan het Mbo

- Leeftijd 16-25 jaar

- Bevoegd om toestemming te geven

Uitsluiting:

- Acute of chronische lichamelijke ziekte waarvoor een langdurige ziekenhuisopname nodig is

- Scholieren die op dat moment geestelijke gezondheidszorg krijgen.

- Onvoldoende begrip van de Nederlandse taal 


\section{Kwalitatief onderzoek}

Om beter te begrijpen waarom de mHealth-interventie invloed heeft op de uitkomsten van de geestelijke gezondheid, en waarom het effect op kinderen met verschillende kenmerken anders kan zijn, stellen we voor een kwalitatief onderzoek uit te voeren onder een deel van de kinderen. Diepteinterviews door volksgezondheidsdeskundigen leveren kwalitatieve informatie op die helpt om de kwantitatieve parameters uit de experimentele onderzoeken te begrijpen.

\section{Experimentele opzet}

Om de causale effectiviteit van deze interventie te testen, kunnen ook in dit geval gerandomiseerde, gecontroleerde veldexperimenten op de Mbo-opleidingen plaatsvinden. De interventie met de mHealth App kan worden gerandomiseerd op het niveau van de klassen. Pre- en postinterventiegegevens over de geestelijke gezondheid van kinderen die worden ingeleverd bij de volksgezondheidsinterventie- en controleklassen kunnen worden verkregen via de PsymateTM applicatie die beschikbaar is op de smartphone. Dat kan allemaal conform de kaders van de AVG worden uitgevoerd.

\section{Treatment}

Om het schoolverzuim en het aantal NEETs te verminderen, proberen we de mentale weerbaarheid en de gezondheid van kinderen te verbeteren. In dit interventieprogramma maken we gebruik van een bestaande mHealth-interventie die via een smartphone-gebaseerde app zal worden toegediend. De interventie dient eenvoudig te worden verspreid (dus app-gebaseerd) en maakt interactief begrip van persoonlijke weerbaarheidsprofielen en verkennend leren in real-time/real-world situaties mogelijk. De interventie zal gebruik maken van elementen van veerkracht en zelfvertrouwen die geschikt zijn voor jongeren (Daemen et al. 2019). SELFIE is een nieuwe Ecologische Momentele Interventie (EMI) die momenteel wordt beoordeeld in een gerandomiseerde gecontroleerde proef. SELFIE, de begeleide zelfhulpinterventie die wordt uitgevoerd via een smartphone-gebaseerde PsyMate ${ }^{\circledR}$ App, maakt interactieve, gepersonaliseerde, real-time en real-world transfervaardigheden mogelijk in het dagelijkse leven van individuen. Het doel van de SELFIE-app is het verbeteren van het gevoel van eigenwaarde. Het bevat een aantal oefeningen die onderwerpen kunnen doen om de veerkracht te verbeteren. De oorspronkelijke SELFIE-interventie bestaat uit drie sessies met een getrainde therapeut, e-mailcontact en de SELFIE-app (www.selfiestudie.nl). In dit onderzoek gebruiken we een aangepaste SELFIE App als een publieke gezondheidsinterventie met klassikale psycho-educatie sessies. 


\section{Registeronderzoek}

Gegevens over de sociaaleconomische en gezinsachtergrond van kinderen, psychometrische testen van schoolprestaties, voortijdig schoolverlaten en NEET zijn beschikbaar bij het Nationaal Cohortonderzoek Onderwijs en CBS; aanvullende verzuim- en uitvalgegevens zijn beschikbaar op scholen, de RMCs en bij de gemeenten. Gegevens uit het praktijkexperiment kunnen worden geanonimiseerd en samengevoegd met de secundaire datasets in de beveiligde data-omgeving van het CBS, waardoor de anonimiteit en de naleving van de AVG-regelgeving wordt gewaarborgd. Analyses van de data om de impact op de volksgezondheid te beoordelen kunnen volledig plaatsvinden in de veilige omgeving van het CBS, waarmee de privacy gewaarborgd is.

\section{Effectevaluatie}

De voorgestelde analyse kan zich richten op twee soorten uitkomstmaten. Ten eerste kunnen we op basis van het experiment analyses doen van de mentale veerkracht en het welzijn van scholieren, gemeten met de Psymate. Ten tweede kunnen we analyses doen die verband houden met het gedrag en de prestaties op school, met name het verzuim, vroegtijdig schoolverlaten en NEET. We verwachten dat mentale gezondheidsproblemen van kinderen gerelateerd zijn aan negatieve onderwijsresultaten, zoals lagere cijfers, hoger risico op zittenblijven, lagere opleidingsniveaus, enz. We verwachten bovendien op basis van de wetenschappelijke literatuur dat de geestelijke gezondheid invloed heeft op het ziekteverzuim en dat het ziekteverzuim invloed heeft op drop-out en NEET. Daarnaast kunnen we via interventies de relatie tussen geestelijke gezondheid en onderwijsuitkomsten verbeteren en de mate waarin deze samenhangen. Tot slot verwachten we heterogeniteit in de manier waarop de interventies kinderen kunnen helpen. Wat voor het ene kind werkt, hoeft niet voor elk kind te werken.

\section{Beleidswijziging}

Het programma kan laten zien of deze interventies werken, waarom, en onder welke omstandigheden. Na evaluatie van de effecten kan beleid worden aangepast, met als doel de effectiviteit van de interventies te vergroten. 


\subsection{Opbrengsten}

Dit experiment kan volgende concrete opbrengsten genereren:

- Het experiment kan het bijdragen aan het terugdringen van het aantal vroegtijdige schoolverlaters en NEET in de provincie Limburg. Het verminderen van het aantal NEETs is een essentiële beleidsdoelstelling voor de Provinciale Staten van Limburg. Door een effectieve interventie te implementeren die tegelijkertijd twee belangrijke voorspellers voor NEETs (geestelijke gezondheidsproblemen en schoolverzuim) tegengaat, kan het aantal NEETs in Limburg aanzienlijk worden gereduceerd. Reductie van het aantal voortijdig schoolverlaters kan daarmee een belangrijke bijdrage leveren aan de preventie van NEETs in Limburg.

- Het effectiviteitsonderzoek kan bovendien bijdragen aan het terugdringen van psychische problemen bij Limburgse jongeren en zo verdere accumulatie van psychische problemen op de lange termijn voorkomen.

- Een wetenschappelijk onderbouwde toets van de effectiviteit van het programma.

- Een rapportage van de bevindingen van het kwalitatieve onderzoek, met daarin de belangrijkste inzichten over de drijfveren van jonge voortijdig schoolverlaters.

- Beleidsadviezen voor gemeenten, provincies, scholen en RMCs, op basis van het onderzoek, en op verzoek presentaties bij de deelnemende stakeholders.

Er zijn ook lange termijnopbrengsten, zowel voor de volksgezondheid als de economie. Ongeveer 8 procent van de Nederlandse kinderen in de leeftijd van 12-25 jaar heeft last van geestelijke gezondheidsproblemen (CBS, 2018). De ziektelast als gevolg van een psychische aandoening is hoog. Dit geldt met name voor de jeugd: 8 van de 10 oorzaken van ziektegerelateerde levensjaren (DALY's) in de leeftijdscategorie 10-24 jaar zijn gerelateerd aan de geestelijke gezondheid en $75 \%$ van de psychische stoornissen ontstaat voor de leeftijd van 25 jaar en 50\% voor de leeftijd van 15 jaar (Kessler e.a. 2005). Door dit programma uit te rollen, neemt ook de ziektenlast af.

\subsection{Voorbereiding en voorwaarden}

Om dit programma te kunnen uitvoeren, is een aantal voorwaarden noodzakelijk. Hieronder vallen:

- Commitment van RMC's, schoolbesturen, schoolleiders en opleidingen. Om de interventie experimenteel te testen alvorensd ze in de hele provincie uit te voeren, willen we samenwerken met het Vista College.

- Deelname door Mbo-scholieren. Deelname vindt plaats op basis van vrijwilligheid. Daarom moet wervingsmateriaal worden geproduceerd en verspreid, en moeten voorlichters op scholen actief 
gaan werven. De mHealth interventie kan ook specifiek worden ingezet als onderdeel van het VSVpreventiebeleid.

- Onderzoekstijd voor de onderzoekers. Onderzoekers van de universiteit zijn daartoe nu intern fondsen aan het aanwerven.

- Toegang tot de registergegevens van het CBS en het NCO, en de technische mogelijkheid de overige gegevens te koppelen aan de registers. Daarbij dient voldaan te zijn aan de door de AVG omschreven randvoorwaarden.

\section{Ten slotte}

Door de implementatie van de in dit rapport omschreven 'interventiestudies kan Limburg de eerste provincie in Nederland worden waar daadwerkelijk evidence based reïntegratie- en preventiebeleid plaatsvindt om kwetsbare jongeren maatschappelijk te laten participeren. De experimentele interventies integreren beleid en onderzoek in een duidelijke, doelmatige cyclus. De vraagstelling komt voort uit een beleidsvraag; de uitwerking van de experimenten is gevoed door onderzoek naar de situatie van NEETs in Limburg. De experimenten leveren het beste bewijs van wat werkt en wat niet, voor wie interventies werken en waarom. Door het beleid vervolgens aan te passen op basis van de bevindingen ontstaan betere interventies. Ook van deze interventies kan de effectiviteit getest kan worden. Zo ontstaat er een cyclus van beleid, onderzoek en verbeteringen, die leidt tot een voortdurende verfijning van de gebruikte aanpak en een voortdurende verbetering van de effectiviteit daarvan. Dit garandeert ook een optimale inzet van publieke middelen.

De twee interventies zijn tegen relatief lage kosten uit te voeren. Wel is verdergaande samenwerking in de Quatro helix nodig. Voor het welslagen van de interventies is een commitment van alle betrokken partijen noodzakelijk. De Provinciale overheid kan een belangrijke rol spelen in de facilitering van die samenwerking. 


\section{Literatuur}

- Bynner, J. and S. Parsons (2002), Social exclusion and the transition from school to work: The case of young people not in education, employment, Journal of Vocational Behaviour, Vol. 60: pp. 289309.

- Bagdi, A., \& Vacca, J. (2005). Supporting Early Childhood Social-Emotional Well Being: The Building Blocks for Early Learning and School Success. Early Childhood Education Journal, 33, 145-150.

- CBS (2015). Meer arbeidsongeschiktheid door psychische klachten. Retrieved from: https://www.trendsinhr.nl/meer-arbeidsongeschiktheid-door-psychische-klachten-dan-doorlichamelijke/

- CBS (2018). 1 op de 12 jongeren is psychisch ongezond. Retrieved from: https://www.cbs.nl/nlnl/nieuws/2018/45/1-op-de-12-jongeren-is-psychisch-ongezond

- Chen, Y.W. (2011), Once a NEET always a NEET? Experiences of employment and unemployment among youth in a job training program in Taiwan, International Journal of Social Welfare, Vol. 20: pp. 33-42.

- Coles, B., S. Hutton, J. Bradshaw, G. Craig, C. Godfrey and J. Johnson (2002), Literature review of the costs of being not in education, employment or training at age 16-18, Research Report, 347, Department of Education and Skills, Nottingham.

- Daemen, M. (2019, June). Ecological Momentary Interventions (EMIs) and an introduction to a novel selfesteem EMI in traumatized youth: The SELFIE-study, Society for Ambulatory Assessment, $6^{\text {th }}$ Biennial Conference, Syracuse, NY.

- Delespaul, P. A. E. G. (1995). Assessing Schizophrenia in Daily Life. The Experience Sampling Method. (PhD). Rijksuniversiteit van Limburg (Maastricht, The Netherlands), Maastricht.

- Eurofound (2012), NEETs. Young people not in employment, education or training: Characteristics, costs and policy responses in Europe. Luxembourg: Publications Office of the European Union.

- Gerritsen SE, Dieleman GC, Beltman MAC, Tangenbergh AAM, Maras A, van Amelsvoort TAMJ, van Staa A. (2019) Transitional psychiatry in the Netherlands: Experiences and views of mental health professionals. Early Interv Psychiatry. Nov 20.

- Gottfried, M. A. (2011). The detrimental effects of missing school: Evidence from urban siblings. American Journal of Education, 117(2), 147-182.

- Kessler RC, Berglund P, Demler O, Jin R, Merikangas KR, Walters EE (2005). Lifetime prevalence and age-of-onset distributions of DSM-IV disorders in the National Comorbidity Survey Replication. Arch Gen Psychiatry. Jun;62(6):593-602.

- Leijdesdorff S, Postma MR, van Kersbergen L, Marchetta N, van Amelsvoort T (2019).No boundaries: a 2 year experience in a specialized youth mental health care program in the Netherlands. Early Interv Psychiatry. Nov 3.

- Leijdesdorff S, Huijs C, Klaassen R, Popma A, van Amelsvoort T, Evers S. Burden of mental health problems: quality of life and cost-of-illness in youth consulting Dutch walk-in youth health centres. J Mental Health, in revision.

- Levels, M., de Grip, A., \& Dicks, A. (2018). NEETs in Limburg: trends, spreiding, en duiding. Research Centre for Education and the Labour Market. ROA Fact Sheets, No. 002, Vol.. ROA-F-2018/

- Levels, M., Dicks, A.., \& de Grip, A (2020). NEET aan 't werk, neet op sjo in Limburg: trends, spreiding, en duiding. Research Centre for Education and the Labour Market. ROA Fact Sheets, No. 004, Vol.. ROA-F-2020/

- OECD (2010), Off to a good start? Jobs for youth, Paris: OECD.

- van Os J, Verhagen S, Marsman A, et al (2017). The experience sampling method as an mHealth tool to support selfmonitoring, self-insight, and personalized health care in clinical practice. Depression and anxiety ;34(6):481-93.

- Rodwell, L., Romaniuk, H., Nilsen, W., Carlin, J. B., Lee, K. J., \& Patton, G. C. (2018). Adolescent mental health and behavioural predictors of being NEET: a prospective study of young adults not in employment, education, or training. Psychological medicine, 48(5), 861-871. 
- Verhagen SJW, Berben JA, Leue C, Marsman A, Delespaul PAEG, van Os J, Lousberg R (2017). Demonstrating the reliability of transdiagnostic mHealth Routine Outcome Monitoring in mental health services using experience sampling technology. PLoS One. Oct 12;12(10):e0186294.

\section{4 LIMBURG}

Dit Technical Report is een onderdeel van het meerjarenprogramma 4Limburg dat een bijdrage wil leveren om de Limburgse samenleving meer duurzaam, vitaal en inclusief te maken. Het doel van dit programma is om, in nauwe samenwerking met de Universiteit Maastricht, Provincie Limburg en ketenpartners zoals gemeenten, UWV en bedrijfsleven, via een trendbreuk de arbeidsparticipatie én de vitaliteit in Limburg naar een hoger niveau te tillen. Voor de Limburgse welvaartsontwikkeling is het van groot belang dat jongeren met de juiste bagage aan de start verschijnen en niet al te vroeg afhankelijk worden van een uitkering. Als opstap voor het te voeren beleid geeft dit Technical Report inzicht in de ontwikkeling van de groep jongeren die geen onderwijs volgen of werk hebben (ook wel aangeduid als de NEETs: "Not in Employment, Education or Training") en inzicht in de omvang van de problematiek in de verschillende gemeentes in Limburg. 